\title{
Biogas Genesis from Vegetable Wastes
}

\author{
Heba Gubara*, P. Subramanian and M.P. Sugumaran \\ Department of Environmental Science, Tamil Nadu Agricultural University, \\ Coimbatore, Tamil Nadu-641003, India \\ *Corresponding author
}

\begin{abstract}
A B S T R A C T
Key words

Vegetable wastes, Biogas, Methane, Anaerobic digestion,

Biomethanation, Batch digestion

Article Info

Accepted:

12 February 2018

Available Online:

10 March 2018

This research investigates the synthesis of biogas from vegetable wastes through anaerobic digestion in batch reactors. The batch test was carried out for a period of 9 weeks, during which the volume of biogas produced from the reactor ad its methane content, was measured. A laboratory test with $2.5 \mathrm{~L}$ bio digester was operated in batch system for the study. The feed material for biogas was a mixture of vegetable wastes which include carrots, tomato, potato and cabbage. The biogas production of the period of the study decreased from a volume of $2015 \mathrm{ml}$ to $235 \mathrm{ml}$ in the ninth week. The methane percent at the maximum was noted to be as 60.32 percent during the second week of biomethanation.
\end{abstract}

\section{Introduction}

In present day's fast growing world, the rate at which energy is consumed is rising at an unexpected rate with every passing day. Many municipal waste management programs do attempt to harness organic waste energy through combustion in waste-to-energy plants and methane collection from microorganism activity in landfills. While such systems make use of the energy available in food waste, they do not directly benefit the individuals who produce the waste, and may also involve additional costs to those individuals related to collection (Donald, 1999). Biogas is methanerich gas produced by the fermentation of plant or crop waste, effluents, cattle dung and nightsoil under anaerobic conditions and is used to generate heat and power (Vijayanand and Singaravelu, 2017).

Biogas-generating technology is a favourable dual purpose technology at present: the biogas generated can be used to meet energy requirements while the organic residue is a useful fertilizer. Biogas is a type of renewable energy that can be produced from the decomposition of animal and plant wastes and is composed of $\mathrm{CH}_{4}, \mathrm{CO}_{2}$ and trace impurities like $\mathrm{H}_{2}, \mathrm{H}_{2} \mathrm{~S}$ and some $\mathrm{N}_{2}$ (Lohri, 2009). The production of methane during the anaerobic digestion of biologically degradable organic matter depends on the amount and kind of the material added to the system. So, leftover 
foods, fruit and vegetable wastes and cow manure may be subjected to anaerobic digestion for energy production in a variety of ways (Chanakyaet al., 2006).

\section{Materials and Methods}

\section{Segregation of wastes}

The waste utilized for biogas generation was derived from the mixture of vegetable wastes. The vegetable waste mixture included a number of vegetable wastes namely cabbage, carrot, potato and tomato (Fig. 1 to 4). The wastes were collected from the local market and were size reduced by shredding.

\section{Preparation of carbon source for Biomethanation}

The wastes shredded were blended together into a single consistent mixture to be used as the feedstock source for biogas genesis in the batch reactors. The figure 5 illustrates the mixed vegetable waste solids without dilution with water. The mixed vegetable waste was diluted with water in 1:1 ratio (Fig. 6) and was fed into the batch reactors (Fig. 7).

\section{Biogas quantification and methane analysis}

The volume of biogas was estimated using downward water displacement with trial setup shown in the figure 8 . The volume of biogas generated was measured at regular intervals and the volume of biogas was noted.

The percent of methane in the biogas was also estimated. The percent of biogas methane was found using a saccharometer. Saccharometer is used to determine the methane content in biogas. Saccharometer is a bent glass tube having graduations in one end and other end sealed. To measure the amount of methane content in the gas, $10 \% \mathrm{NaOH}$ or $\mathrm{KOH}$ solution was filled into the saccharometer.
Then, $5 \mathrm{ml}$ of biogas was injected using a syringe. The $\mathrm{CO}_{2}$ present in the biogas is dissolved in the alkali solution, where methane is collected at the top of the saccharometer. The volume of alkali displace is the content of the methane.

Volume of dissolved biogas

Methane content $=$ $\mathrm{x} 100$

Volume of biogas injected

\section{Results and Discussion}

The various data pertaining to biogas production, the percentage of methane in biogas were recorded over the period of study. The biogas volume was recorded daily over a period of nine weeks, the methane percent in the biogas was also analysed.

The volume of biogas produced over the period of study is shown in the histogram in figure 9. From this result it can be seen that the average biogas production during the first four weeks were maximum as2015, 1430, 1150 and $1175 \mathrm{ml}$.

Then the average biogas production fell below $1000 \mathrm{ml}$ in the consecutive weeks reducing to the lowest of $235 \mathrm{ml}$ during the ninth week of biomethanation. The trend can be seen from the figure 9, during the fifth week the average biogas production fell below $1000 \mathrm{ml}$ range as $970 \mathrm{ml}$. This further reduced to $660 \mathrm{ml}$ in the sixth week and as $545 \mathrm{ml}$ in the seventh week, finally as $395 \mathrm{ml}$ in the eight week of biomethanation, before hitting the lowest value of $235 \mathrm{ml}$ in the final week of biogas genesis (Fig. 10).

Such similar results were observed by Das and Mondal, 2016, in which the average biogas yield increased and then decreased over the period of digestion using the carbon source for biomethanation as kitchen and vegetable organic wastes. 

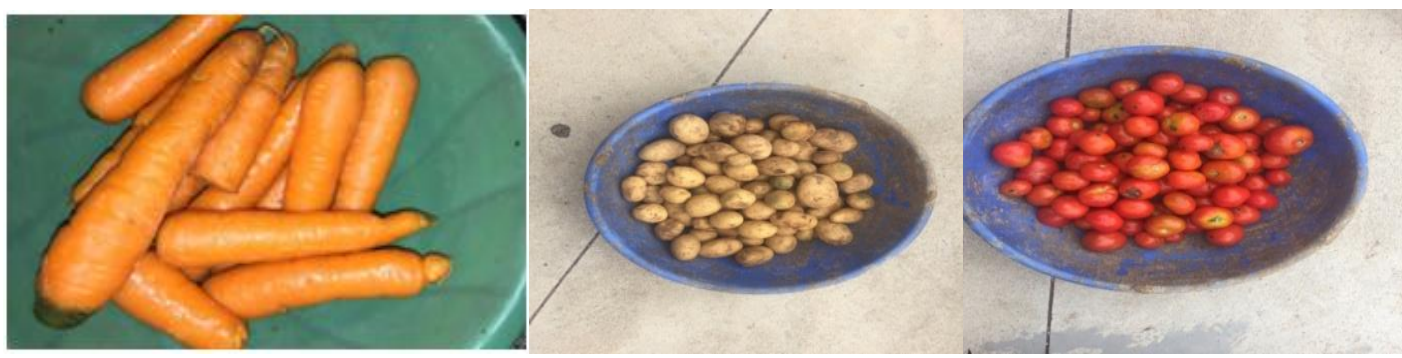

Fig.1 Collected Waste Carrot, Potato and Tomato

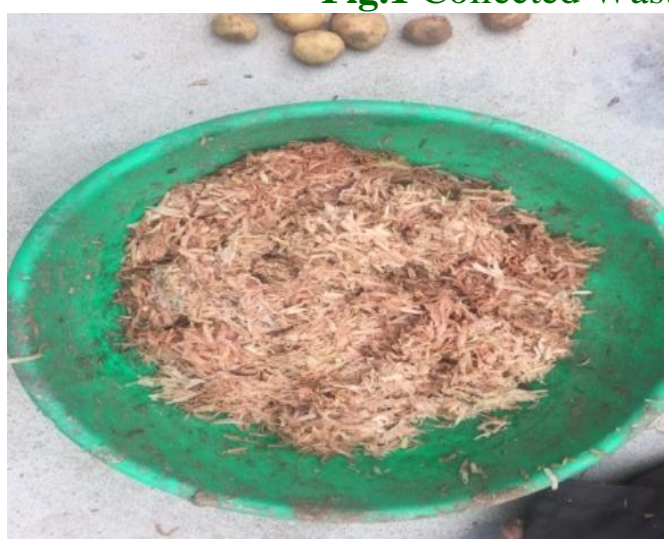

Fig.2 Prepared Potato waste

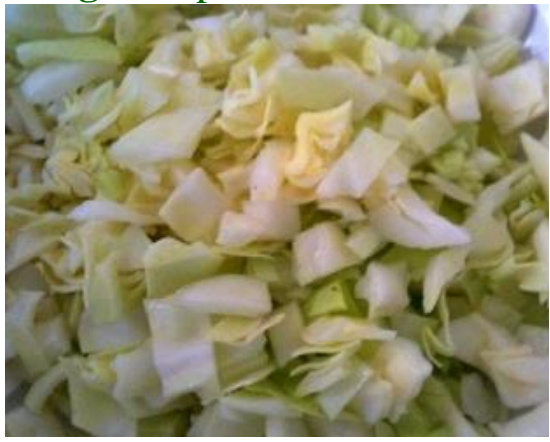

Fig.4 Prepared of Cabbage Waste

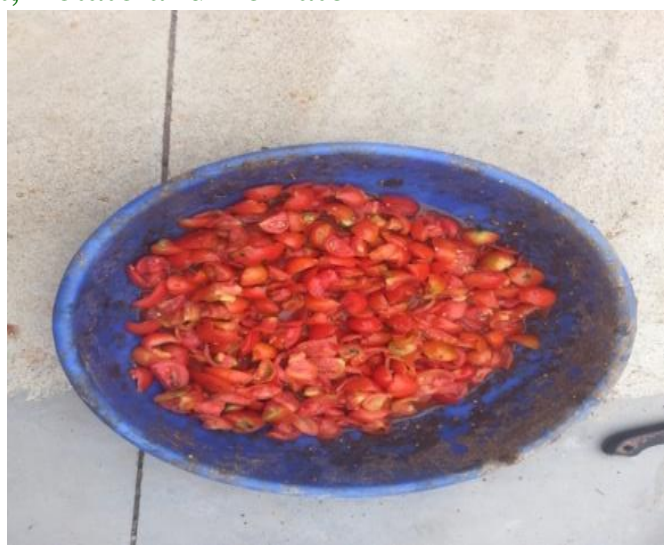

Fig.3 Prepared Tomata waste

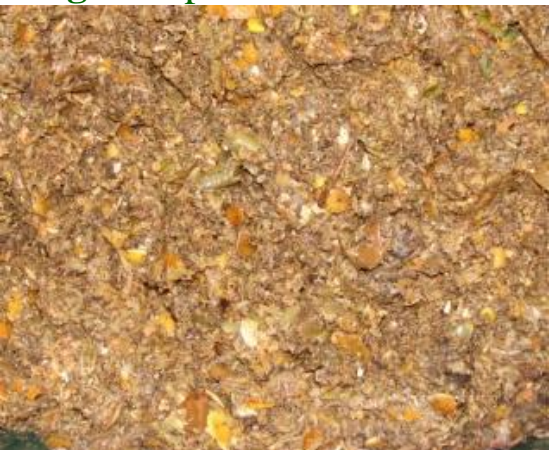

Fig.5 Vegetable waste slurry after blending for batch experiments

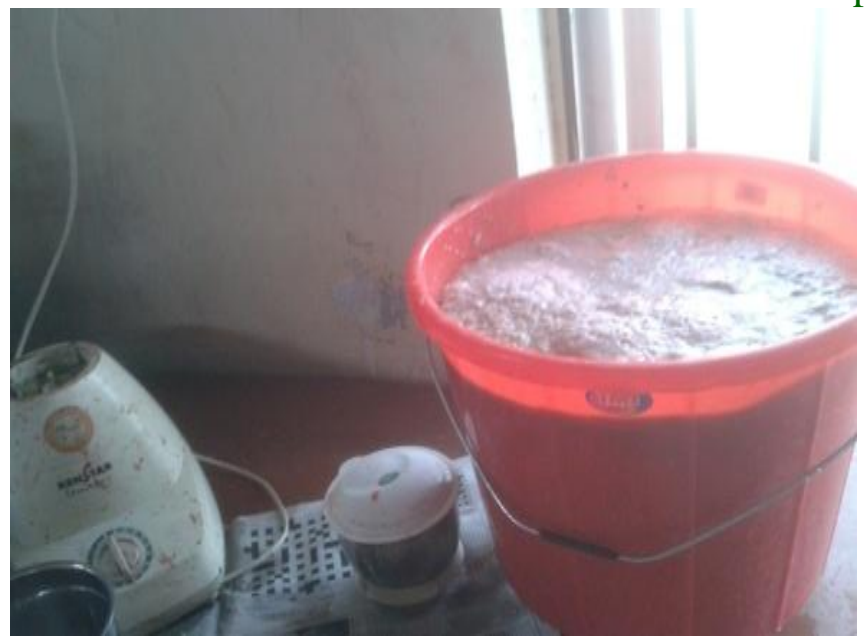

Fig.6 Condition of vegetable market wasteafter dilluted 


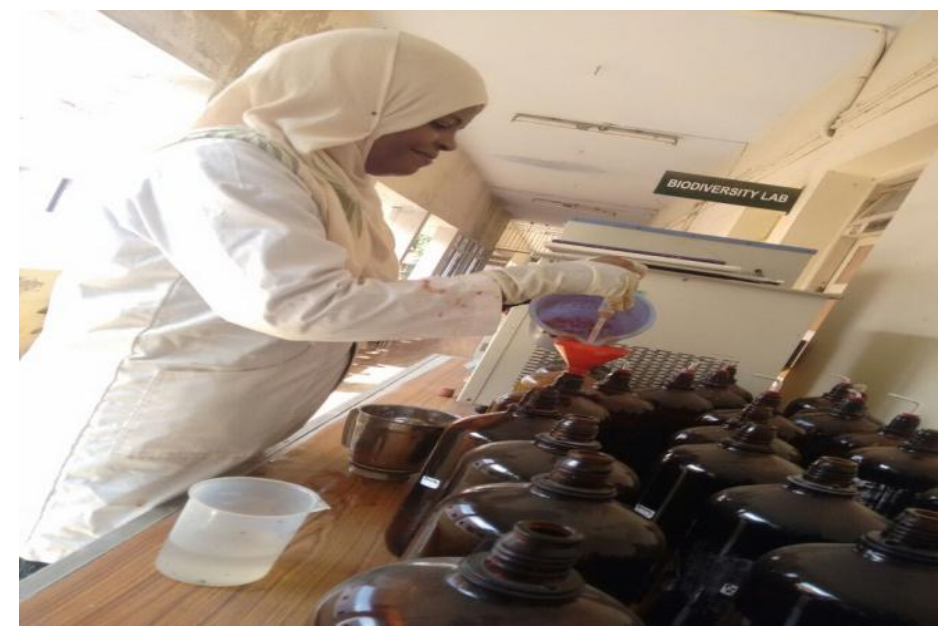

7(a)

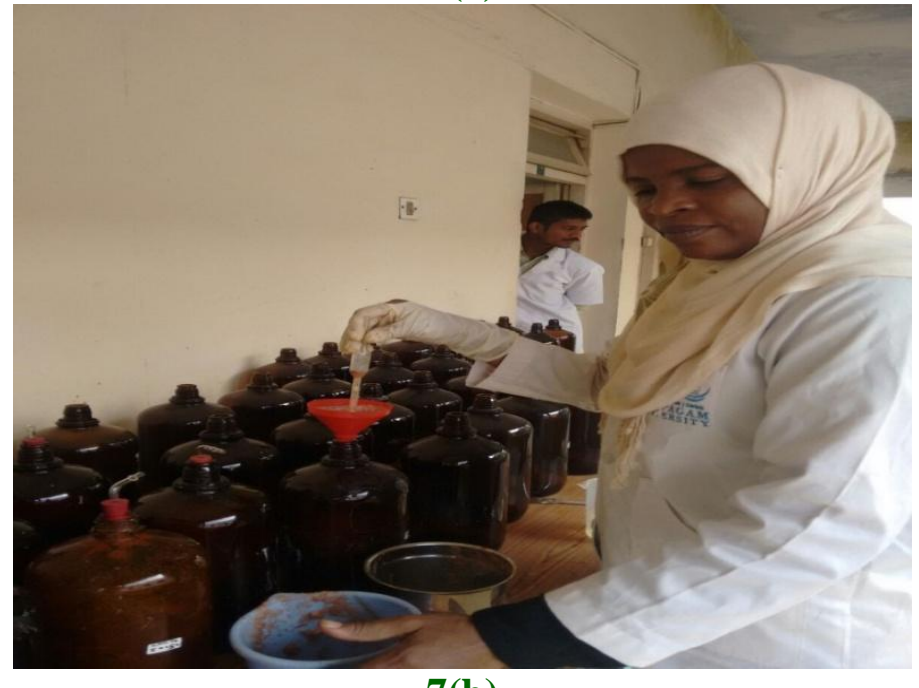

7(b)

Fig.7 Feeding of vegetable waste slurry into batch reactors $(2.5 \mathrm{~L}$ bottle)

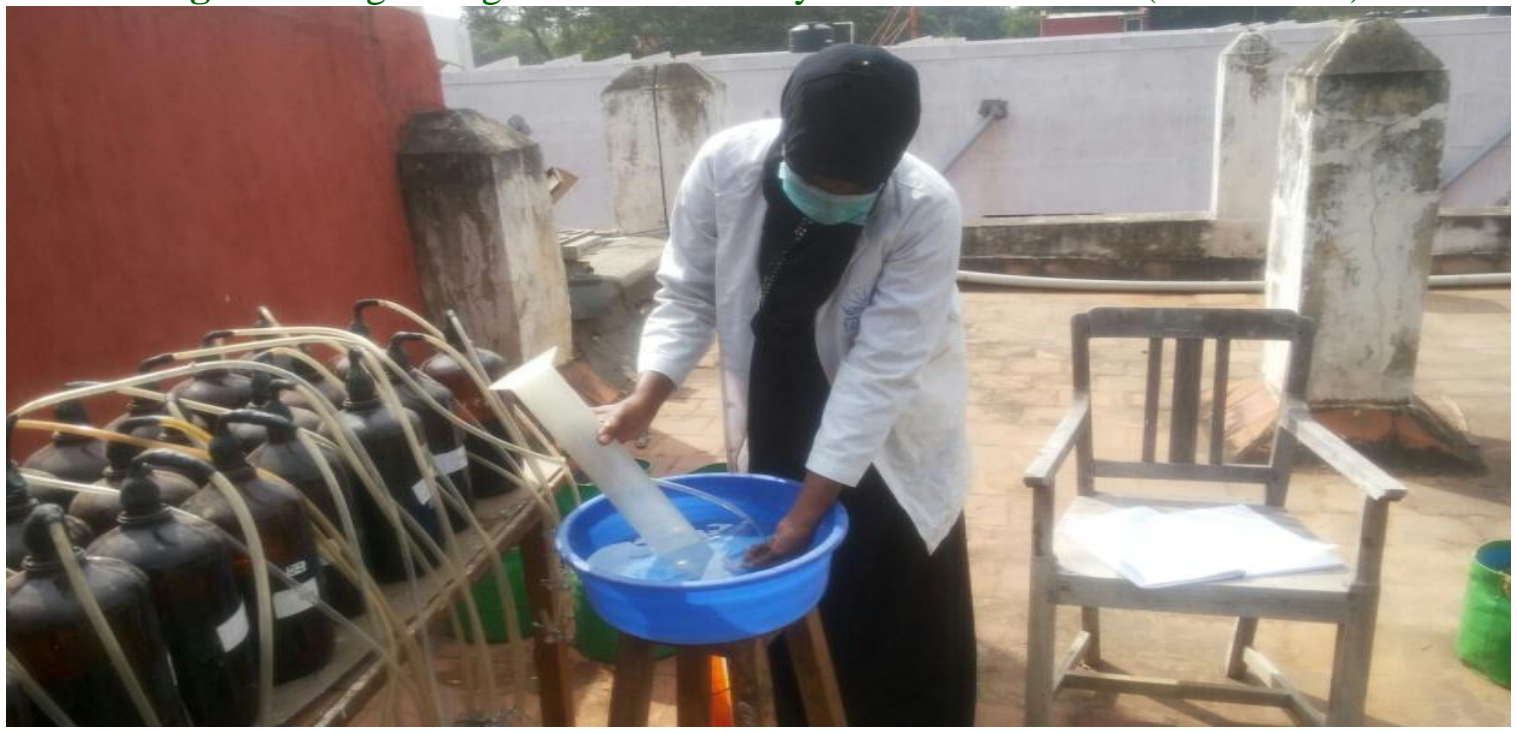

Fig.8 Biogas measurement using water displacement method 


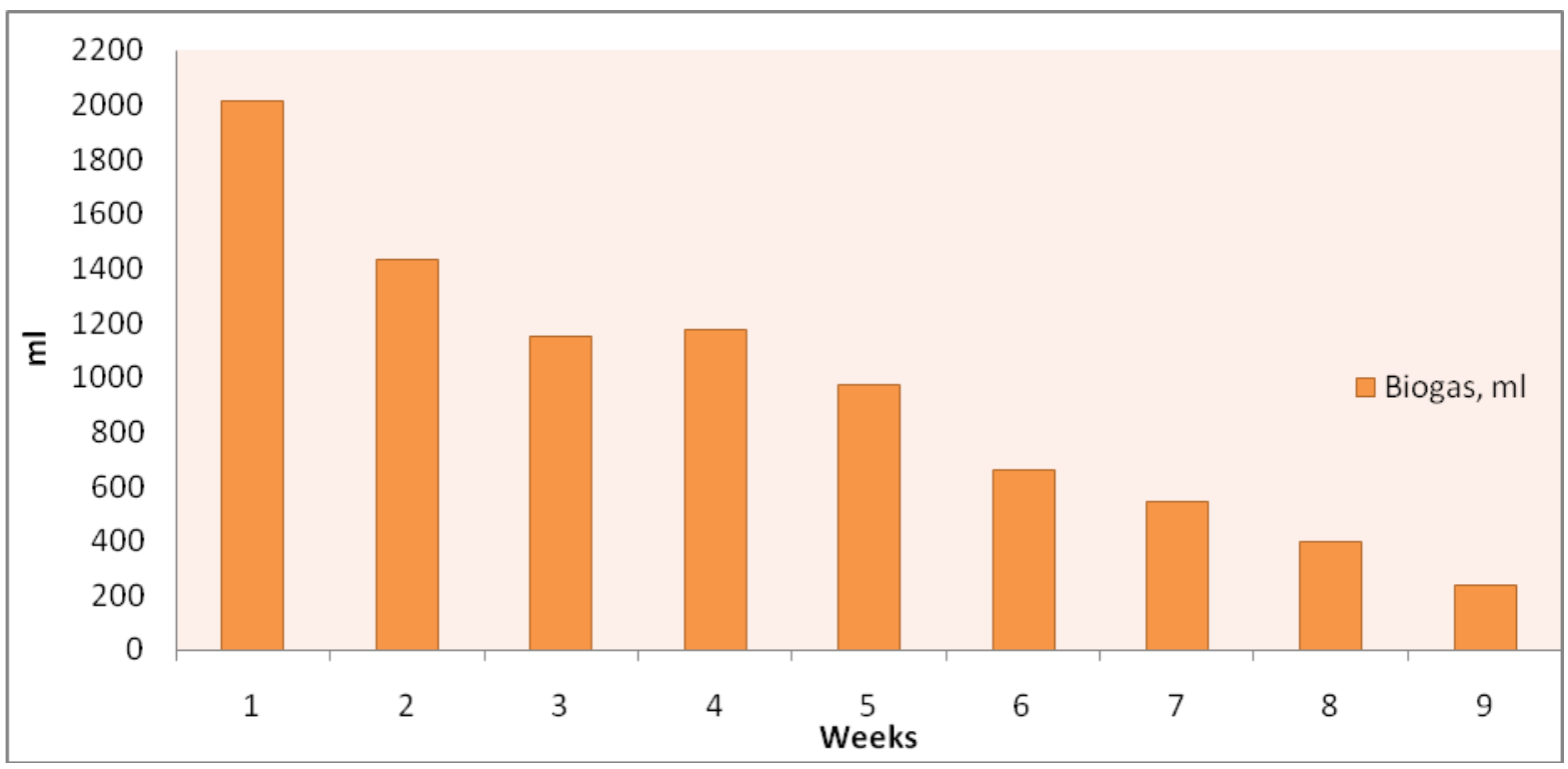

Fig.9 Average volume of biogas produced from batch trials using vegetable wastes

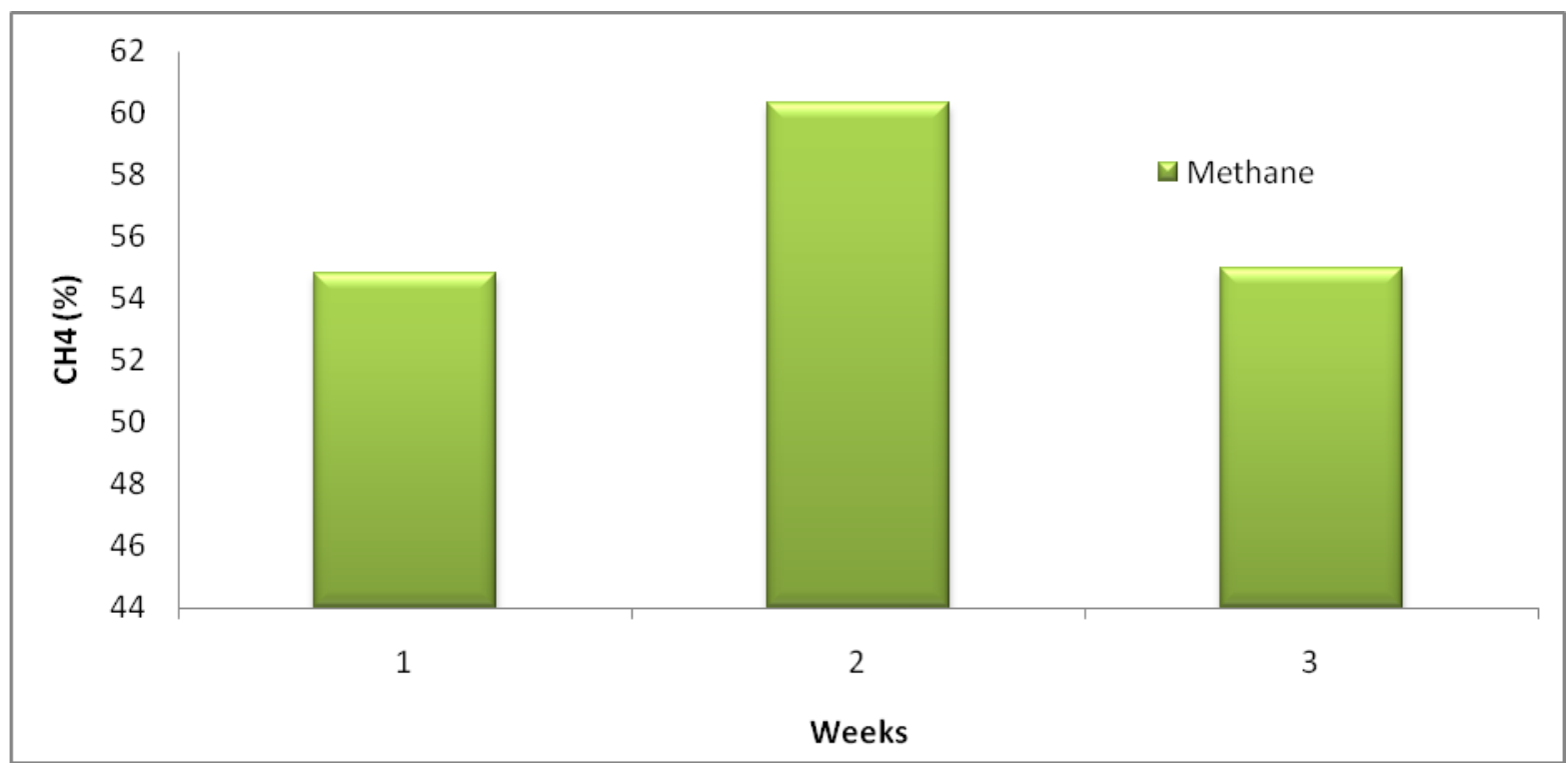

Fig.10 Average methane percent in first three weeks

The average methane percent in the biogas during the first week of biomethanation was 54.82 percent which surged to 60.32 percent during the second week of biomethanation. While during the third week of biomethanation, the methane value decreased to 55 percent almost equal to that of the first week's average methane production value. The methane values detected in the analysis were observed to be normal values within the expected range, also indicates a healthy population of methanogenic bacteria inside the batch reactors.

Biogas generated from the biomethanation process contains about 50 to65 per cent of methane, carbon dioxide, hydrogen sulphide, water vapour and traces of ammonia (Kapadi et al., 2005).

With the rising prices of fossil fuels, there is an alarming need for switching over to 
renewable fuels and utilization of fuels generated from wastes. Biogas is renewable source of fuel that can be generated from all organic wastes and effluents. From the results obtained in this study, the use of vegetable wastes is a promising option for generating biogas for household cooking and lighting in off grid rural areas. Further the biodigested slurry can be used as manure for roof gardening as well as fields. The digested slurry can also be fed as feed for vermicomposting by mixing with cattle dung.

\section{References}

Chanakya, H.N., Ramachandra, T.V., Vijagachamundeeswari, M. 2006. Anaerobic digestion and reuse of digested products of selected products of urban solid waste.

Das A and Mondal C.2016. Biogas Production from Co-digestion of Substrates: A Review. International
Research Journal of Environment Sciences Vol. 5(1), 49-57.

Donald, L. 1998. Biomass for Renewable Energy, Fuels and Chemicals; Academic Press. 445-491.

Kapdi SS, Vijay VK, Kempegowda RS and Prasad R 2005. Biogas scrubbing, compression and storage: perspective and prospects in Indian context. Renewable Energy 30(8): 1195-1202.

Lohri, C. 2009. Research on anaerobic digestion of organic solid waste at household level in Dares Salaam, Tanzania; Bachelor Thesis at ZHAW (Zurich University of Applied Sciences) in collaboration with Eawag (Swiss Federal Institute of Aquatic Science and Technology).

Vijayanand C and M Singaravelu. Installation of a biogas upgradation system. Agric International 4(1): 12-15, 2017; doi: $10.5958 / 2454-8634.2017 .00003 .1$

\section{How to cite this article:}

Heba Gubara, P. Subramanian and Sugumaran, M.P. 2018. Biogas Genesis from Vegetable Wastes. Int.J.Curr.Microbiol.App.Sci. 7(03): 1412-1417. doi: https://doi.org/10.20546/ijcmas.2018.703.169 